\title{
RESEARCH IN SPORT PHYGICAI ACTI \\ Anxiety and perceived psychological stress play an important role in the immune response after exercise
}

Autor(es): $\quad$ Edwards, Jason P.; Walsh, Neil P.; Diment, Bethany C.; Roberts, Ross

Publicado por: Imprensa da Universidade de Coimbra

URL persistente:

URI:http://hdl.handle.net/10316.2/44138

DOI:

DOI:https://doi.org/10.14195/2182-7087_ex2018_75

Accessed : $\quad$ 26-Apr-2023 15:20:28

A navegação consulta e descarregamento dos títulos inseridos nas Bibliotecas Digitais UC Digitalis, UC Pombalina e UC Impactum, pressupõem a aceitação plena e sem reservas dos Termos e Condições de Uso destas Bibliotecas Digitais, disponíveis em https://digitalis.uc.pt/pt-pt/termos.

Conforme exposto nos referidos Termos e Condições de Uso, o descarregamento de títulos de acesso restrito requer uma licença válida de autorização devendo o utilizador aceder ao(s) documento(s) a partir de um endereço de IP da instituição detentora da supramencionada licença.

Ao utilizador é apenas permitido o descarregamento para uso pessoal, pelo que o emprego do(s) título(s) descarregado(s) para outro fim, designadamente comercial, carece de autorização do respetivo autor ou editor da obra.

Na medida em que todas as obras da UC Digitalis se encontram protegidas pelo Código do Direito de Autor e Direitos Conexos e demais legislação aplicável, toda a cópia, parcial ou total, deste documento, nos casos em que é legalmente admitida, deverá conter ou fazer-se acompanhar por este aviso. 


\section{ANNALS OF RESEARCH IN SPORT AND PHYSICAL ACTIVITY}




\title{
ANXIETY AND PERCEIVED PSYCHOLOGICAL STRESS PLAY AN IMPORTANT ROLE IN THE IMMUNE RESPONSE AFTER EXERCISE
}

\author{
Jason P. Edwards'; Neil P. Walsh; Bethany C. Diment²; Ross Roberts³
}

KEYWORDS: Running, Immunity, In vivo, Diphencyprone, STAI

There are common pathwaysby whichpsychological stress and exercise stress alter immunity ${ }^{(1)}$, and there has been a recent call to physiologists ${ }^{(2)}$ and exercise immunologists(3) to incorporate objective psychological measurements in their human studies. However, it remains unknown whether psychological stress plays a role in the in vivo immune response to exercise. The aim of this study was to examine the relationship between anxiety and perceived psychological stress reported before exercise and in vivo immunity after exercise using skin sensitisation with Diphenylcyclopropenone (DPCP). Sixty-four males completed widely used psychological instruments to assess state-anxiety and perceived psychological stress before exercise, and ran either 30 minutes at $60 \%(30 \mathrm{MI})$ or $80 \%(30 \mathrm{HI}) \mathrm{VO}^{\prime} \mathrm{O}_{2 \text { peak }}$ ' 120 minutes at $60 \%(120 \mathrm{MI}) \mathrm{V}^{\prime} \mathrm{O}_{2 \text { peak }}$ or rested (CON) before DPCP sensitisation. Cutaneous recall to DPCP was measured 4-weeks after sensitisation. After accounting for exercise $\left(R^{2}=0.20 ; P<0.01\right)$, multiple-regression showed that pre-exercise state-anxiety (STAI-S; $\left.\triangle R^{2}=0.19 ; P<0.01\right)$ and perceived-stress $\left(\triangle R^{2}=0.13 ; P<0.01\right)$ were associated with the DPCP response after exercise. The STAI-S scores before exercise were considered low-to-moderate (median split; mean STAI-S of low, 25 and moderate, 34) and further examination showed that the DPCP response after exercise $(30 \mathrm{MI}, 30 \mathrm{HI}$ or $120 \mathrm{MI})$ was $62 \%$ lower in low vs. moderate state-anxiety $(P<0.01)$. In conclusion, state-anxiety and perceived psychological stress levels before exercise play an important role in determining the strength of the in vivo

\footnotetext{
1 College of Health and Behavioural Sciences, Bangor University, Bangor, UK.

2 2College of Health and Behavioural Sciences, Bangor University, Bangor, UK; Norwich Medical School, University of East Anglia, Norwich, UK.

3 Institute for the Psychology of Elite Performance, Bangor University, Bangor, UK.

Email: n.walsh@bangor.ac.uk
} 
immune response after exercise. As such, investigators should account for psychological stress when examining the immune response to exercise.

\section{REFERENCES}

1. Perna, F. M., Schneiderman, N., \& LaPerriere, A. (1997). Psychological Stress, Exercise and Immunity. Int J Sports Med, 18(S 1), S78-S83.

2. Wehrwein, E. A., \& Carter, J. R. (2016). The Mind Matters: Psychology as an Overlooked Variable Within Physiology Studies. Physiology (Bethesda), 31(2), 74-75.

3. Walsh, N. P., \& Oliver, S. J. (2016). Exercise, immune function and respiratory infection: An update on the influence of training and environmental stress. Immunol Cell Biol, 942), 132-139. 